\title{
THE MYOCARDIAL EFFECTS OF PANCURONIUM
}

\author{
P.C. Duke, ${ }^{*}$ H. Fung, $†$ and J. Gartner ${ }^{*}$
}

SEVERAL CLINICAL STUdies have shown that pancuronium bromide usually produces some improvement in blood pressure, heart rate and cardiac output following its administration. ${ }^{1-3}$ The mechanism responsible for these cardiovascular changes has been attributed to a partial blockade of myocardial muscarinic receptors by pancuronium. Bonta, et al. observed that pancuronium selectively blocks cardiac muscarinic receptors and reverses the negative inotropic and chronotropic effects of carbachol, methacholine and acetylcholine in animal preparations in vivo and in vitro. ${ }^{3-6}$ Loh has suggested other possible mechanisms are responsible for the observed cardiovascular changes produced by pancuronium, such as sympathetic ganglionic stimulation or a direct positive inotropic effect. ${ }^{7}$ Sympathetic ganglionic stimulation should result in an increase in circulating catecholamines. However, Zsigmond, et al. observed no increase in plasma norepinephrine levels in man up to ten minutes following the administration of pancuronium. ${ }^{8}$ The purpose of these investigations was to determine if pancuronium had a direct positive inotropic effect on the myocardium by studying its effect on myocardial contractility in three different animal preparations.

\section{Methods}

\section{Rabbit Atrial Strips}

Rabbits weighing 2 to $3 \mathrm{kgm}$ were stumned by a blow on the head. Left atrial strips were isolated and were immediately suspended in a heated tissue bath containing Krebs-Henseleit solution. The solution was vigorously aerated with 95 per cent $\mathrm{O}_{2}$ and 5 per cent $\mathrm{CO}_{2}$ and maintained at a physiological $\mathrm{pH}$ and a temperature of $37^{\circ} \mathrm{C}$ (Figure 1). Changes in isometric tension were observed by means of a force displacement transducer (Grass FT-0.3) and recorded on a polygraph (Grass model 7). Each atrial strip was attached to platinum clip electrodes and stimulated at a rate of 1 per sec using a square wave pulse generator at supermaximal voltage. The atrial muscle strips were preloaded to a tension of $2 \mathrm{gm}$. Each preparation was allowed to equilibrate and stabilize for a period of 30 minutes prior to study. Incremental concentrations of pancuronium bromide ranging from $10^{-8} \mathrm{gm} / \mathrm{ml}$ up to $10^{-5} \mathrm{gm} / \mathrm{ml}$ were maintained in the bath and the force of atrial contraction was measured at each concentration. Results were expressed as a percentage change in force of contraction from that obtained during a drugfree control period.

From the Departments of Anesthesiology, Medicine and Pharmacology, $\uparrow$ Health Sciences Centre-General and Faculty of Medicine, University of Manitoba.

Supported by Grant MA 3525 from the Medical Research Council of Canada. 


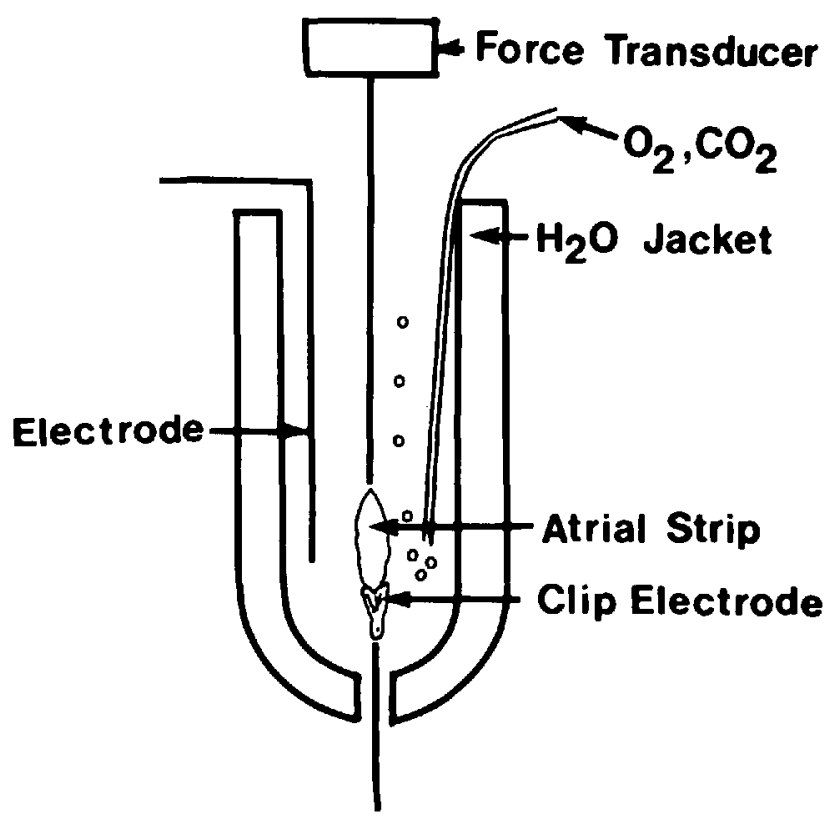

Figure 1. Atrial strip and papillary muscle are attached to a stimulating electrode and force displacement transducer in a heated water bath.

\section{Cat Papillary Muscle}

Papillary muscle was obtained from cats weighing approximately $2 \mathrm{~kg}$ in the same manner as for the previous experiment. This was suspended in the same water bath with the same force displacement apparatus. Stimulating characteristics were identical to the atrial strip experiments. Drug-free control tensions were observed. The effect of the addition of incremental doses of acetylcholine ranging from $10^{-7} \mathrm{gm} / \mathrm{ml}$ to $10^{-3} \mathrm{gm} / \mathrm{ml}$ on contractile force were observed. This was referred to as the control dose-response curve for acetylcholine. The bath was then washed thoroughly and the resting tension of the muscle was allowed to return to the drug-free control level. Pancuronium bromide in concentration of $10^{-8} \mathrm{gm} / \mathrm{ml}$ was then added to the bath and contractile changes were observed alone and in the presence of the same incremental doses of acetylcholine utilized in the acetylcholine dose-response control. Results were expressed as a percentage change in contraction from the drug-free control.

\section{Intact Atropinized Dogs}

Five healthy mongrel dogs weighing between 16 and 27.5 kilograms were studied. Anaesthesia was induced by face mask with increasing concentrations of halothane in a 70 per cent -30 per cent nitrous oxide-oxygen mixture, delivered by a standard anaesthetic circuit. When the animal was anaesthetized, the trachea was intubated and end-tidal halothane concentration was maintained at 1.1 per cent to 1.2 per cent (approximately $1.25 \mathrm{MAC}$ ) in oxygen by utilizing a Beckman IR-215A infra red analyzer. Ventilation was contolled with an Ohio anaesthetic respirator. A period of 30 to 45 minutes was allowed for anaesthetic equilibration and stabiliza- 
tion of the animals, prior to the commencement of our studies. During this period a carotid artery and external jugular vein were cannulated. Direct arterial pressure was sensed with a Statham p-23 Db transducer attached to the carotid artery catheter. Central venous pressure was sensed by Statham p-23 BB transducer connected to a venous catheter with the tip placed in the right atrium. Placement of the atrial catheter was verified by pressure measurements. Arterial blood gases and phasic and mean arterial and venous pressures were recorded throughout the experimental period. Respiratory rate and tidal volume were adjusted to maintain an arterial $\mathrm{P}_{\mathrm{CO}}$ between 35 and 40 torr. Cardiac output was determined by the dye dilution technique. The dye was injected into the right atrium while arterial blood was continuously withdrawn through a Waters Recording Densitometer (Model DCR-701) by a Sage pump. Withdrawn blood was reinfused after each study. Body temperature was continuously monitored and maintained between $36^{\circ}$ and $38^{\circ} \mathrm{C}$ with a heating blanket. Heart rate was obtained from recordings of lead II of a standard three limb electrocardiogram. Total peripheral resistance was calculated from the cardiac output and mean pressure recordings in the usual manner.

Cardiac output, heart rate, phasic and mean arterial and venous pressures and arterial blood gases and $\mathrm{pH}$ studies were performed during the halothane control, ten minutes after administration of atropine $(0.5 \mathrm{mgm} / \mathrm{kg})$. Following these measurements a bolus of pancuronium $(0.08 \mathrm{mgm} / \mathrm{kg})$ was injected and studies were repeated five and ten minutes later. All data were expressed as a percentage of values obtained during the halothane control.

\section{Results}

There was no statistical change in the force of contraction of rabbit atrial strips over the concentration range designated in the five preparations studied (Figure 2).

The addition of incremental concentration of acetylcholine to the water bath containing the papillary muscle preparation produced a standard dose-response curve for acetylcholine (Figure 3 ). With increasing acetylcholine concentrations contractile force progressively decreased. In the presence of pancuronium at a concentration from $10^{-8} \mathrm{gm} / \mathrm{ml}$, the curve was shifted to the right. This shows that pancuronium partially blocks the effect of acetylcholine muscarinic receptors. Pancuronium alone in the water bath produced no change in the force of contraction from the drug-free control.

After atropinization of the dogs, cardiac output, heart rate and stroke volume increased, with no change in the mean arterial blood pressure (Table I). Total peripheral resistance decreased as expected. Five and ten minutes after the bolus administration of pancuronium there was no additional change in these values, as illustrated in Figure 4.

\section{Discussion}

These data show that in the preparations studied in vivo and in vitro, pancuronium does not have a direct positive inotropic effect.

In the papillary muscle preparations, pancuronium did not exhibit a stimulating effect per se on ventricular muscle but blocked the negative inotropic effect of 


\section{\% $\triangle$ Force of contraction}

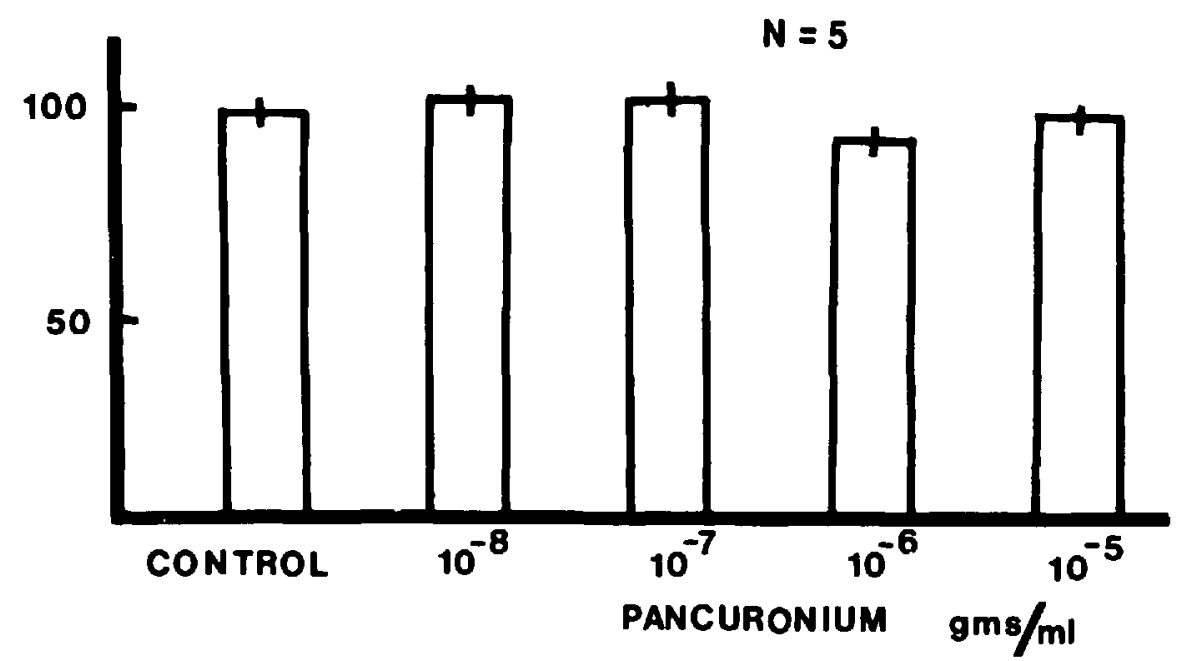

Figune 2. Rabbit atrial strip preparations show no change in the force of contraction (mean \pm S.E.) fom the drug-free control.

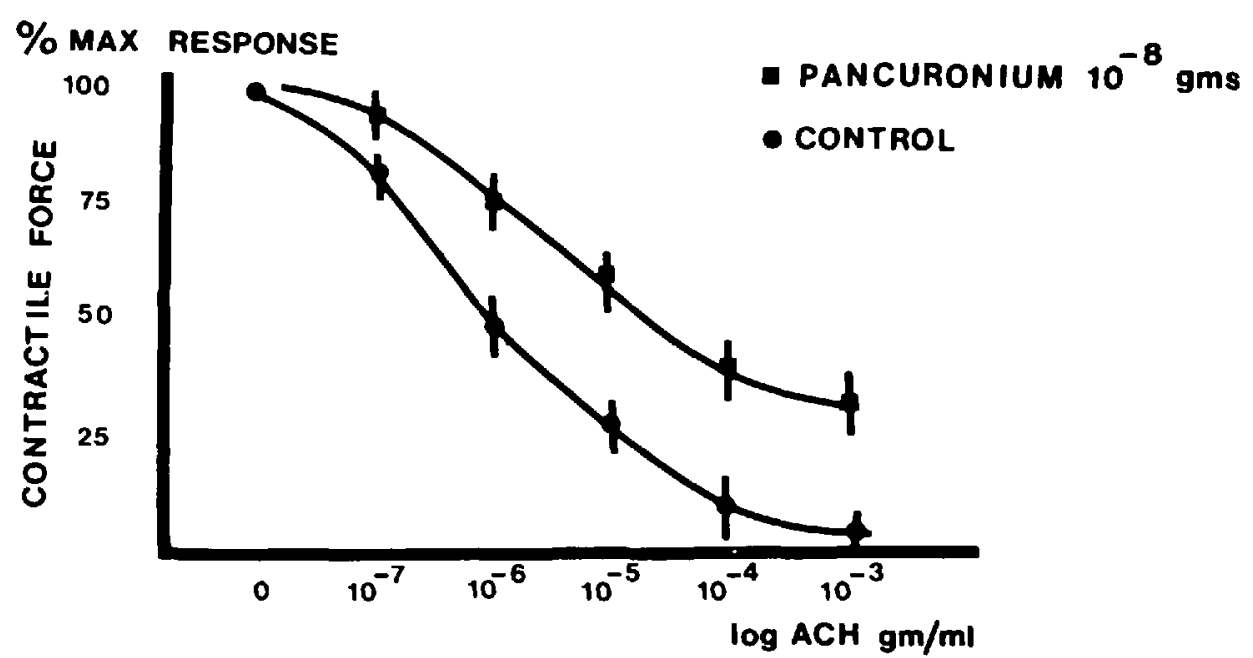

Figure 3. Changes in the force of contraction (mean \pm S.E.) of pancuronium on the dose response curve of the negative inotropic action of acetylcholine in cat papillary muscle preparations. Note the parallel shift of the curve to the right showing a competitive antagonism by pancuronium. Pancuronium alone does not change force of contraction of the papillary muscle preparation.

acetylcholine on the myocardium. Goat has demonstrated a similar ability of pancuronium to antagonize the effect of acetylcholine in isolated rabbit hearts. ${ }^{9}$ Our data substantiates the findings of Bonta et al. who initially demonstrated the muscarinic blocking activity of this drug. ${ }^{5.6}$ Our studies differ in that we utilized a lower concentration of pancuronium (i.e. $10^{-8} \mathrm{gm} / \mathrm{ml}$ vs. $10^{-5} \mathrm{gm} / \mathrm{ml}$ ) to demonstrate its effect on the acetylcholine dose-response curve. 


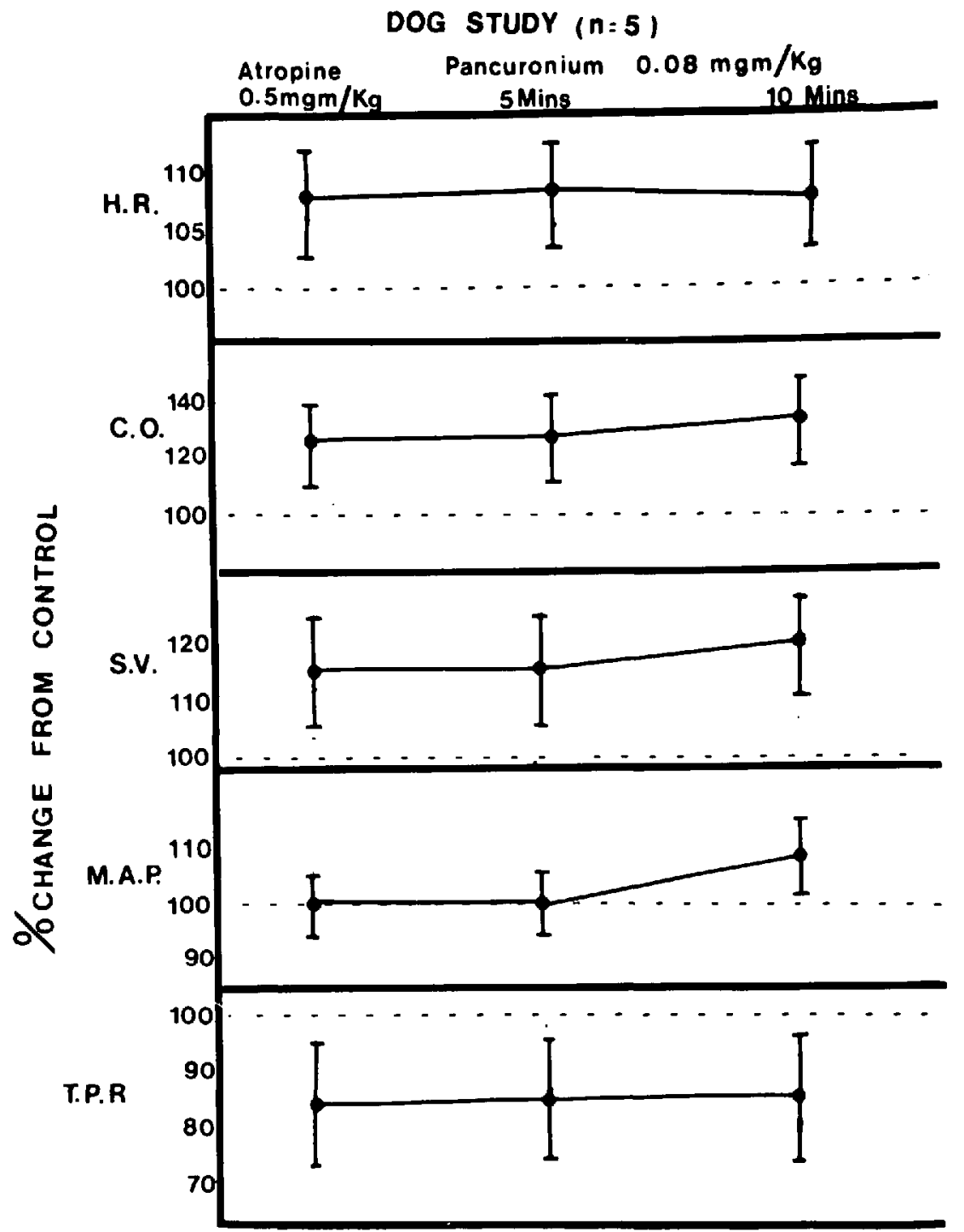

Ficure 4. Changes expressed as percentage change from $1 \mathrm{MAC}$ halothane control (average \pm S.E.), five minutes after atropinization and five and ten minutes after pancuronium 0.08 $\mathrm{mgm} / \mathrm{kg}$. C.O. = cardiac output; H.R. = heart rate; S.V. = stroke volume; M.A.P. = mean arterial pressure; T.P.R. = total peripheral resistance. Note the absence of change in values following the administration of pancuronium.

Human studies similar to our intact dog experiments have been reported by Colman, et al. ${ }^{1}$ After atropinization, pancuronium administered in doses of 0.1 $\mathrm{mgm} / \mathrm{kg}$ did not produce significant changes in cardiac output, heart rate, stroke volume or total peripheral resistance. We feel that our evidence, along with these other studies, substantiates the observation that the cardiovascular effects of pancuronium are due solely to its ability to block cardiac muscarinic receptors selectively and that it does not have a direct positive inotropic effect on the myocardium. 


\section{SUMMARY}

The effect of pancuronium on myocardial contractility was studied in three different animal preparations. Pancuronium produced no change in isometric contraction of rabbit atrial or cat papillary muscle but displaced the acetylcholine dose-response curve to the right in the papillary muscle preparations, verifying a muscarinic blocking effect of this drug. In atropinized dogs in vivo pancuronium produced no significant change in the cardiovascular parameters studied. These studies show that pancuronium exerts its cardiovascular effects primarily by blocking muscarinic receptors in the heart.

\section{RÉSUMÉ}

L'action du Pancuronium sur la contractilité du Myocarde a été étudiée au moyen de trois préparations animales. Le Pancuronium n’a pas modifié la contraction isométrique du muscle auriculaire de lapin et du muscle papillaire de chat.

On a cependant observé une déviation à droite de la courbe de réponse à des doses croissantes d'acétylcholine; ceci confirme que le Pancuronium est un bloqueur de l'activité muscarinique.

Chez des chiens atropinisés, le Pancuronium n’a pas modifié de façon significative les paramètres cardio-vasculaires étudiées.

Nous concluons de ces études que les effets cardio-vasculaires du Pancuronium sont dus principalement à un blocage des récepteurs muscariniques cardiaques.

\section{ACKNOWLEDGMENTS}

The authors are grateful to Mr. W. Pucci for his excellent technical help and Dr. W.A. Tweed for his literary comments.

\section{REFERENCES}

1. Coleman, A.J., Downing, J.W., Leary, W.P., Moyes, D.G., \& Styles, M. The immediate cardiovascular effects of pancuronium, alcuronium, and tubocurarine in man. Anaesthesia 27: 415-422 (1972).

2. Kelman, G.R. \& Kennedy, B.R. Cardiovascular effects of pancuronium in man. Brit. J. Anaesth. 43: 335-338 (1971).

3. Stoelting, R.K. The hemodynamic effects of pancuronium and d-tubocurarine in anesthetized patients. Anesthesiology 36:612-615 (1972).

4. Bonta, I.L., Goonissen, E.M., \& Derkx, F.H. Pharmacological interaction between pancuronium bromide and anesthetics. Eur. J. Pharmacol. 4: 83-90 (1968).

5. SAXENA, P.R. \& Bonta, I.L. Mechanism of selective cardiac vagolytic action of pancuronium bromide. Specific blockade of muscarinic receptors. Eur. J. Pharmacol. 11: 332-341 (1970).

6. Saxena, P.R. \& Bonta, I.L. Specific blockade of cardiac muscarinic receptors by pancuronium bromide. Arch. Int. Pharmacodyn. 189: 410-412 (1971).

7. LoH, L. The cardiovascular effects of pancuronium bromide. Anesthesia 25: 356-363 (1970)

8. Zsigmond, E.K., Matsuki, A., Kothary, S.P., \& Kelsch, R.C. The effect of pancuronium bromide on plasma norepinephrine and cortisol concentrations during thiamylal induction. Canad. Anaesth. Soc. J. 21: 147-152 (1974).

9. GoAT, V.A. The action of muscle relaxants on cholinergic mechanisms in the heart. In: Spierdijk, J. and Feldman, S.A. (ed.) Anesthesia and Pharmaceutics. Proc. Boerhaave Course, University Press, Leiden, 48-62 (1972). 